\title{
KEBIJAKAN PELESTARIAN SUMBER DAYA HUTAN DALAM RANGKA PEMBANGUNAN BERKELANJUTAN
}

\author{
Oleh: Nursalam*)
}

\begin{abstract}
Abstrak
Pelestarian hutan kini menjadi perhatian banyak negara termasuk Indonesia karena kondisi hutan dunia saat ini telah mengalami deforestasi yang memprihantinkan. Diperlukan kebijakan yang mendasar agar masalah kehancuran hutan dapat diatasi. Untuk itu kebijakan yang ditempuh oleh berbagai negara adalah dengan menerapkan paradigma pembangunan kehutanan yang berkelanjutan, yaitu bertumpu pada keseimbangan antar keberlanjutan fungsi ekonomi, ekologi dan sosial budaya dari pengelolaan sumberdaya hutan yang tidak sentralistik dengan membangun kemandirian masyarakat. Selain itu untuk mencapai tujuan dari pada kebijakan kehutanan maka salah satu syarat yang harus dipenuhi adalah keterlibatan aktif masyarakat dalam melestarikan sumber daya hutan. Partisipasi mereka dalam pelestarian sangat penting mengingat bahwa mereka adalah penentu (subjek) dan sekaligus yang merasakan dampak kebijakan tersebut (objek).
\end{abstract}

Kata Kunci: Kebijakan, Pelestarian hutan, Pembangunan berkelanjutan.

\section{Pendahuluan}

Keberhasilan sektor kehutanan dalam menunjang pertumbuhan ekonomi ternyata membawa dampak terhadap kerusakan lingkungan, diindikasikan dengan semakin rusaknya hutan atau telah terjadi deforestasi. Menurut laporan FAO setiap tahun rata-rata 1,871 juta hektar yang hancur atau $2 \%$ dari luas hutan yang tersisa pada tahun 2005, yakni 88,495 Juta hektar (kompas, 5 Mei 2007). Indonesia dinilai merupakan negara yang paling parah laju deforestasinya di dunia. Tingkat kerusakan ini telah menempatkan Indonesia pada pengelolaan yang tidak lestari. Hasil pengkajian menunjukkan bahwa setidaknya ada 2 faktor yang menyebabkan kerusakan lingkungan dan sumberdaya hutan yaitu; (1) tidak berimbangnya porsi kegiatan pemanfaatan dengan kegiatan rehabilitasi hutan dalam kebijakan pengelolaan hutan; (2) pemanfaatan yang lebih terkonsentrasi pada pemanfaatan hasil hutan kayu. Orientasi dan kebijakan pemerintah dalam pengelolaan sumberdaya hutan dinilai hanya berorientasi kayu (timber oriented).

Merujuk kepada fenomena deforestasi dan peranan hutan dalam pembangunan berkelanjutan, maka pelestarian sumber daya alam khususnya hutan telah menjadi bagian utama dari perhatian bidang sosial, ekonomi, dan politik.

Ilmu pengetahuan konservasi telah digabungkan dengan kampanye tentang kesadaran publik, partisipasi, dan ekonomi yang berkelanjutan. Program

\footnotetext{
* Penulis adalah Staf Pengajar Jurusan Ilmu Administrasi Negara FISIP Universitas Nusa Cendana Kupang
} 
lingkungan perserikatan bangsa-bangsa (PBB) yang dikutif dari Jeffries (2006:173) meringkaskan perlunya kebutuhan tentang hal ini, yaitu untuk:

1) mengintegrasikan pendekatan-pendekatan yang berbeda dalam upaya menjamin kemungkinan secara luas pelestarian berbagai keanekaragaman hayati.

2) mengenal bahwa pelestarian sangat dipengaruhi oleh faktor sosial, budaya, ekonomi, dan politik.

3) mendorong kerjasama dan koordinasi dari kebijakan dan kelembagaan.

Strategi konservasi dunia yang dikutip dari Jeffries (2006:174) telah membagi 3 unsur dari pada strategi pelestarian, yaitu: Perlindungan (protection), menggunakan secara berkelanjutan (sustainable use), dan membagi bersama manfaat penggunaannya (sharing the benefits). Pasal 1 perjanjian Rio biodiversity telah mempertegas mengenai pelestarian keanekaragaman hayati termasuk hutan, menggunakann secara berkelanjutan, unsur strategi dan membaginya secara adil dan layak manfaat keanekaragaman hayati tersebut. Perlindungan terhadap keanekaragaman hayati saat ini dikaitkan dengan eksploitasi yang berkelanjutan.

\section{Pendekatan Pelestarian}

Negara-negara berkembang telah mengarahkannya, dimulai dengan partisipasi atau pelestarian yang didasarkan pada masyarakat. Mengembangkan pendekatan yang mengakui bahwa masyarakat setempat (local) harus dilibatkan dan mendapat manfaat dari skema atau rencana pelestarian.

Perubahan budaya mengenai pelestarian telah memberikan dampak yang berarti sehingga banyak negara memberikan perhatian pada masalah ini dengan merespon pasal 1 perjanjian Rio Biodiversity, tentang upaya untuk menggabungkan prinsip-prinsip ekologi dengan ekonomi dan keberlanjutan. Di Inggris pekerjaan pendahuluan digerakkan oleh kerjasama antara dewan konservasi alam dan departemen lingkungan yang mengindentifikasi empat (4) masalah yaitu: perlindungan dan pembentukan manajemen area; penggunaan secara berkelanjutan; keterlibatan masyarakat; serta pengumpulan data dan informasi.

Menurut Indrawan et al (2007: 288), penentuan kawasan yang dilindungi dapat dilakukan dengan berbagai cara yaitu:

1) Kebijakan pemerintah. Umumnya kebijakan ini dihasilkan pada tingkat nasional, misalnya peraturan pemerintah. Di samping itu, kebijakan dapat dilakukan pada tingkat regional atau lokal, peraturan daerah atau peraturan desa.

2) Pembelian lahan yang dilakukan oleh perseorangan maupun organisasi konservasi. Sebagai contoh, sebuah kemitraan global telah mengalokasikan dana untuk mewujudkan konsesi hutan tanpa penebangan di Sumatra.

3) Mendukung budaya dan adat masyarakat setempat.

4) Pendirian stasiun penelitian lapangan (yang menggabungkan perlindungan hayati dan penelitian dengan pendidikan konservasi) oleh universitas maupun instansi penelitian lainnya.

Kerjasama antar pihak terkait merupakan cara baru untuk mendukung kawasan yang dilindungi. Kerjasama ini dapat meliputi berbagai hal termasuk 
pendanaan, pelatihan, bantuan ilmiah, dan keahlian pengelolaan. Partisipasi masyarakat terhadap perlindungan kawasan tetap ada jika pengelola kawasan tetap melindungi dan melestarikan tempat dan penghidupan mereka.

Menurut Johnson (1995:23) terdapat 3 pertanyaan yang perlu dijawab yang dijadikan dasar untuk menentukan prioritas konservasi terhadap suatu sumber daya, yaitu: Apa yang perlu dilindungi, di mana wilayah yang perlu dilindungi dan bagaimana cara melindunginya?. Selanjutnya Indrawan et al (2007: 301) mengemukakan bahwa terdapat tiga kriteria yang dapat digunakan untuk menjawab pertanyaan tersebut di atas yaitu:

1) Kekhasan. Suatu komunitas hayati diberi prioritas yang lebih tinggi bagi konservasi bila memiliki lebih banyak spesies langka dan endemic. Sebaliknya komunitas yang terdiri atas spesies yang umum serta tersebar luas pada umumnya tidak mendapat prioritas yang tinggi. Suatu spesies dapat bernilai lebih tinggi bila secara taksonomi bersifat unik.

2) Keterancaman. Spesies yang menghadapi ancaman kepunahan membutuhkan penanganan lebih dibandingkan dengan spesies yang tidak terancam.

3) Kegunaan. Spesies yang memiliki kegunaan nyata atau berpotensi bagi manusia perlu diberikan prioritas konservasi yang lebih tinggi dibandingkan spesies yang tidak memilki kegunaan langsung bagi manusia. Komunitas hayati dengan nilai ekonomi yang tinggi juga diberikan perhatian yang khusus.

Menggunakan ketiga kriteria tersebut, pengembangan sistem prioritas dengan sasaran spesies maupun komunitas dapat dilakukan pada tingkat nasional maupun internasional, pendekatan tersebut biasanya saling melengkapi. Pendekatan spesies diterapkan dalam membuat prioritas konservasi adalah dengan melindungi spesies tertentu. Melindungi spesies berarti juga melindungi seluruh komunitas hayatinya. Kawasan konservasi seringkali didirikan untuk melindungi spesies langka. Pendekatan spesies dilakukan berdasarkan pedoman rencana penyelamatan (survival plan) yang dirancang oleh pemerintah maupun organisasi non pemerintah bagi spesies tertentu. Disamping menginformasikan spesies yang membutuhkan perlindungan, pedoman penyelamatan juga memberikan mengenai wilayah dengan prioritas konservasi yang tinggi. Para ahli bertugas mengevaluasi, memberikan rekomendasi, dan menyusun rencana kerja. Seringkali untuk menentukan batas kawasan, serta menentukan spesies dan komunitas yang harus diprioritaskan, keputusan harus dilakukan dengan cepat.

Pendekatan lain yang digunakan adalah pendekatan ekosistem dan komunitas. Sasaran utama bagi upaya konservasi adalah komunitas dan ekosistem, sedangkankan spesies hanya menjadi sasaran kedua. Ekosistem akan member manfaat banyak bagi masyarakat karena berfungsi banyak, termasuk mengendalikan banjir, menyediakan makanan bagi hewan ternak atau untuk rekreasi. Konservasi ekosistem tidak hanya melindungi spesies, namun juga melindungi ekosistem untuk menjalankan fungsinya dan jasa-jasa lingkungan terkait.

Menurut Berkes dan Folke (2000:156), Wilayah yang tidak dilindungi, termasuk yang bertetangga dengan kawasan yang dilindungi merupakan elemen 
penting bagi strategi konservasi, mengingat lebih dari $85 \%$ lahan dunia yang berada di luar kawasan konservasi, strategi perlu dirancang untuk pelestarian di luar kawasan konservasi. Tidaklah efektif bila melindungi spesies tertentu hanya dalam kawasan yang dilindungi. Pendekatan tersebut akan menimbulkan paradox. Di satu sisi, spesies dan habitat yang berada dalam kawasan yang dilindungi akan terlindungi, namun spesies dan habitat yang berada di luar kawasan tidak terlindungi, sehingga selanjutnya menyebabkan turunnya populasi spesies di dalam kawasan. Pada kawasan yang tidak dilindungi lainnya, spesies tertentu dapat bertahan karena kepadatan manusia dan tingkat pemanfaatannya relatif rendah.

Upaya mendorong serta membantu pemilik lahan perorangan maupun pengelola lahan pemerintah untuk melindungi spesies langka dan komunitas tentunya penting untuk meningkatkan keberlangsungan hidup spesies tertentu.

Menurut Brooks et al (2003:1639), di banyak Negara pemerintah berusaha menginformasikan keberadaan dan lokasi spesies langka serta komunitas yang terancam kepada pengembang infrastruktur untuk membantu pihak terkait untuk menyesuaikan rencana mereka agar kerusakan lingkungan dapat dapat dihindari. Program pendidikan kepada masyarakat dan bantuan dana juga dibutuhkan dalam mengembangkan upaya konservasi.

Salah satu hal yang juga penting berkaitan dengan upaya keberhasilan pelestarian hutan adalah pentingnya perhatian terhadap pengelolaan ekosistem. Konsep yang dipakai mengacu kepada konsep yang digunakan oleh Grumbine (1994:35), yaitu :

Pengelolaan ekosisten memadukan pengetahuan ilmiah mengenai berbagai hubungan ekologi, di dalam kerangka pemikiran sosial ekonomi dan nilainilai yang rinci serta mengarah pada tujuan umum berupa perlindungan keutuhan ekosistem alami dalam jangka waktu yang panjang.

Praktik pengelolaan sumber daya alam, yang selama ini menekankan produksi maksimun, baik berupa barang (volume kayu yang dipanen), maupun jasa (jumlah pengunjung dalam kawasan) perlu diperkaya dengan sudut pandang yang lebih tepat dan meluas sehingga mencakup pelestarian hutan serta perlindungan ekosistem. Menurut Stanley (1995:257) bahwa dalam pengelolaan ekosistem terdapat beberapa tema penting yaitu:

1) Memastikan keberlanjutan (viability) semua spesies, serta kelangsungan hidup berbagai perwakilan komunitas hayati maupun seluruh tahapan suksesi yang ada, dan menjaga agar ekosistem sehat dan berfungsi dengan efektif.

2) Mencari serta memahami hubungan antara tiap tahap maupun skala yang beroperasi dalam hirarki suatu ekosistem, mulai dari tingkatan individu, spesies, komunitas hingga ekosistem bahkan mencapai skala regional dan global.

3) Memantau komponen-komponen penting ekosistem (jumlah individu dari spesies yang dianggap penting, tutupan vegetasi, kualitas air, dan sebagainya), serta mengumpulkan data yang diperlukan, dan menggunakan hasilnya untuk menjalankan praktik pengelolaan sesuai keadaan setempat. 
4) Memahami bahwa manusia merupakan bagian dari ekosistem, dan bahwa penilaian manusia akan memengaruhi tujuan pengelolaan. Selanjutnya, perlu dikembangkan pemahaman bersama bahwa mengelola sumber daya secara berkelanjutan akan memberikan manfaat berjangka panjang pula.

Sisi lain yang perlu juga diperhatikan berkaitan dengan prinsip prinsip konservasi adalah aspek tata pemerintahan yang baik (good governance), Menurut UNDP, good governance merupakan suatu kesepakatan yang diciptakan oleh pemerintah, masyarakat dan sektor swasta, berikut diuraikan prinsip-prinsipnya dalam kaitan dengan upaya pelestarian sebagaimana dikemukakan oleh Indrawan $e t$ al (2007: 539-541), yaitu:

1) Partisipasi. Berkaitan dengan partisipasi, masalah utamanya adalah bagaimana meningkatkan peran serta publik, dan lebih jauh, bagaimana memindahkan pelayanan birokrasi kepada masyarakat, di sinilah otonomi daerah mempunyai peluang untuk berperan, dimana fungsi pelayanan akan didelegasikan ke pemerintah daerah serta desa dan bahkan masyarakat melalui kemitraan yang secara sosial bersifat inklusif. Azas partisipasi merupakan dasar yang penting bagi pola manajemen sumber daya alam secara efektif. Dari sini dikenal prinsip "ecological stewardship", yang sejalan dengan berbagai hak ulayat tertentu. Untuk mewujudkan azas partisipasi perlu dikembangkan mekanisme hukum dan ekonomis, berupa insentif dan disintensif yang dapat mendorong agar hakhak dan kepemilikan (masyarakat) setempat dihargai sewajarnya.

2) Kepastian hukum. Hukum yang berkaitan dengan kehutanan di Indonesia, misalnya masih tumpang tindih dan simpang siur. Hak-hak masyarakat adat dalam mengelola SDA telah terinstitusi dari generasi ke generasi. Karena itu hak-hak tersebut perlu dihormati, dilindungi dan digunakan (ditegakkan) sebagai dasar pembangunan sumber daya manusia, pengelolaan SDA dean pengaturan tata ruang.

3) Transparansi. Dalam bidang pemanfaatan keanekaragaman hayati, dibutuhkan pembagian keuntungan yang adil dan berimbang (fair and equitable sharing of benefits). Bagaimana hal tersebut dicapai, informasi-informasi yang berkaitan dengan kebijakan publik, termasuk hasil-hasil auditing biaya-biaya produksi dan pemanfaatan sumber-sumber daya alam perlu dikelola agar mudah diakses masyarakat. Salah satu mekanisme yang efektif adalah dengan membangun konsultasi publik, dan dialog pihak-pihak dengan pihak terkait secara terus menerus.

4) Bersifat tanggap. Pola manajemen sumber daya alam perlu bersifat adaptif. Suka atau tidak, tata pemerintahan dipengaruhi oleh mekanisme pasar, sehingga diperlukan leveraging change through the market. Dalam kaitannya dengan otonomi daerah maka perlu didesiminasikan pelatihan-pelatihan di daerah terhadap topik yang relevan, termasuk memenuhi kesepakatan global (multilateral environmental agreement).

5) Pengembangkan kesepakatan. Pembagian tugas dan wewenang yang jelas diperlukan bagi berlangsungnya pemerintahan yang efektif. Konflik 
kewenangan antar tingkat perlu diselesaikan dengan berbagai mekanisme musyawarah, termasuk di antaranya melalui proses lembaga arbitrase.

6) Kesetaraan. Termasuk di dalamnya kesetaraan jender, perlu diingat bahwa dalam banyak hal seringkali perempuan membuktikan dirinya sebagai pengelola sumber daya alam yang lebih efisien dan efisien dibandingkan dengan laki-laki. Di samping kesetaraan jender, sistem kepemilikan, akses, dan pemanfaatan sumber daya alam perlu diperbaiki.

7) Efektif dan efisien. Perhatian yang lebih besar harus diberikan pada stok, dan tidak hanya pada produk serta komoditas. Labih lanjut produksi sumber daya alam perlu diefisienkan agar dapat berkelanjutan. Mekanisme pemantauan dan pengendalian yang efektif perlu dikembangkan serta diaplikasikan, misalnya sertifikasi atau ekolabel. Di samping itu, ketergantungan terhadap bahan bakar fosil secara bertahap perlu dihilangkan, sementara upaya-upaya penerapan energi terbarukan harus terus dikembangkan. Pada saat bersamaan perlu dikembangkan mekanisme-mekanisme agar terwujud pembangian keuntungan yang adil dan berimbang.

8) Bertanggung-gugat. Semua pihak harus bertanggung gugat, baik pemerintah, swasta, maupun masyarakat madani. Bagi pihak swasta maka tanggung gugat perlu mencakup aspek-aspek sosial maupun ekologi.

9) Visi strategi. Perspektif luas dan jauh ke depan merupakan inti dari visi strategis ini, perlu disadari bahwa manajemen sumber daya alam merupakan isu utama pembangunan berkelanjutan. Sistem-sistem adat dan tradisional yang telah dikembangkan berabad-abad perlu mendapat legitimasi yang wajar. Tantangan langsung otonomi daerah, yaitu bagaimana menanggulangi kontradiksi peningkatan pendapatan asli daerah dengan konservasi lingkungan hidup, perlu dihadapi. Rencana-rencana pembangunan SDM, pemanfaatan SDA, serta tata ruang wilayah harus dirancang mulai dari tingkat kabupaten dan provinsi, dan diharmonisasikan dengan kebijakan tingkat nasional melalui proses dua arah.

\section{Konsep Pelestarian Hutan}

Salah satu elemen penting dalam pengelolaan hutan adalah konsep pelestarian, khususnya menyangkut kelestarian hasil hutan. Sejak pertama kali lahir sampai sekarang, definisi kelestarian hasil hutan telah mengalami perkembangan dan bervariasi dari satu negara ke negara lain. Pada mulanya suatu hutan dianggap dimanfaatkan secara lestari bila tebangan tahunan atau tebangan periodik tidak mengurangi kapasitas hasil dan bila setelah penebangan dilakukan diseluruh kawasan hutan, potensi tegakan dilapangan tidak berkurang dengan sebelum dilakukan penebangan (Simon, $2006: 20$ ). Konsep mengenai kelestarian hasil ini mengalami perubahan sebagaimana dikemukakan oleh Wiebecke dan Peters (1984: 68) bahwa:

The endeavor to facilitate the continuous and optimal provision of all tangible and intangible effects of the forest for the benefit of human being of present and future generations. 
Oleh karena itu konsep kelestarian hasil hutan sekarang pada umumnya dianggap mempunyai hubungan dengan lingkup yang lebih luas dari segi ekologi dan sosial ekonomi suatu wilayah.

Sisi lain tentang konsep kelestarian hasil hutan dalam pengelolaan hutan adalah konsep hutan normal, konsep ini berhubungan erat dengan teknik silvikultur dan sistem pengaturan hasil yang dipakai (Simon, 2006: 22). Menurut Osmaton dalam Simon (2006: 91) hutan normal adalah hutan yang dapat mencapai dan menjaga derajat kesempurnaan hutan untuk memenuhi ketentuan sesuai dengan tujuan pengelolaan.

Secara ideal hutan normal merupakan tegakan dengan persebaran kelas umur yang merata dan riap yang maksimal. Tebangan tahunan atau tebangan periodik pada hakikatnya harus sama dengan riap untuk jangka waktu yang bersangkutan. Dengan demikian hasil kayu yang maksimal dapat diperluas sepanjang waktu tanpa membahayakan hasil dimasa yang akan datang. dan oleh karena itu kelestarian hutan dapat dipertahankan. Karena kelestarian hasil dapat berarti tebangan hutan atau periodik sama dengan riap tahunan, maka besarnya tebangan dapat dihitung sama dengan riap tahunan pada saat sekarang (current increment). Pandangan ini merupakan landasan metoda pengaturan hasil berdasarkan riap saja. Masalahnya adalah bagaimana riap pada saat sekarang ditaksir atau diukur. Melalui cara ini penaksir hanya melihat pengaturan hasil berdasarkan jumlah pohon dan ukuran diameter. Dengan cara ini akan mudah diidentifikasi apakah pohon tersebut telah lestari. (Simon, 2006: 28).

Untuk tetap mempertahankan tingkat kelestarian hutan seperti yang diinginkan, Forest Stewardship Counsil (FSC) dan European Forest Certification (PEFC) yang merupakan organisasi yang mengembangkan standar pengelolaan hutan berkelanjutan, yang ditetapkan oleh masing-masing institusi (Sastroprawiro, 2008). Standar FSC menetapkan sepuluh prinsip sebagai prasyarat hutan kelas dunia yang baik, setiap prinsip memiliki kriteria dan indikator sebagai persyaratan pemenuhan pengelolaan hutan yang baik (hutan bersertifikasi), kesepuluh prinsip itu adalah:

1) Complience with law FSC principle, yaitu mengarahkan pengelola untuk mematuhi semua peraturan hukum nasional dan internasional terkait dengan kegiatan usahanya serta prinsip FSC.

2) Tenure and use rights and responsibilities, yaitu mengarahkan pengelola hutan untuk bertanggung jawab terhadap hak penguasaan dan penggunaan lahannya.

3) Indigenous people's rights, yaitu mengarahkan pengelola untuk menghargai hak masyarakat lokal disekitar area pengelolaan sehingga terjadi simbiosis mutual.

4) Community relations and worker rights, yaitu mengarahkan pengelola untuk berhubungan baik dan atau bekerja sama dengan masyarakat disekitarnya dan mematuhi hak karyawan sesuai peraturan.

5) Benefit from the forest, yaitu mengarahkan pengelola hutan untuk mengindentifikasi dan mencatat semua manfaat dari hutan yang dikelola, termasuk manfaat untuk masyarakat sekitar. 
6) Environmental impact, yaitu mengarahkan pengelola agar menjalankan tata kelola dengan seminimal mungkin merusak lingkungan hidup.

7) Management plan, yaitu mensyaratkan pengelola memiliki perencanaan kerja yang baik untuk aspek rencana produksi, sosial dan lingkungan dalam menjalankan kegiatannya.

8) Monitoring and assesment, yaitu mensyaratkan pengelola memantau secara sistimatis semua aktivitas kerja serta melakukan penilaian periodik guna melakukan perbaikan.

9) Maintenance of high conservation value forest, yaitu mengarahkan pengelola untuk menjaga dan memelihara area di dalam lingkup kerjanya yang terbukti memiliki nilai konservasi tinggi, misalnya sumber mata air utama, habitat satwa liar, dan cagar budaya.

10) Plantation, yaitu mengarahkan pengelola hutan tanaman memenuhi prinsip satu sampai sembilan dan kriteria konservasi yang ditetapkan FSC untuk hutan tanaman.

\section{Kebijakan Pembangunan Kehutanan Berkelanjutan}

Hutan sebagai salah satu sumber daya alam adalah anugerah Tuhan Yang Maha Esa, memiliki berbagai manfaat bagi kehidupan, yaitu berupa manfaat langsung bisa dirasakan (tangible) dan manfaat yang tidak langsung (intangible).

Menurut State of world's Forests yang diterbitkan FAO pada tahun 1999 yang dikutip dari Boenjamin (1991: 25), Indonesia memiliki kawasan hutan tropis terluas kedua di dunia setelah Brazil. Kekayaan sumberdaya hutan sebagaimana digambarkan, memberi arti penting bagi Indonesia baik dari aspek ekonomi, sosial, dan lingkungan serta untuk masyarakat.dari fungsi hutan sebagai penyerap karbon dan nilai keanekaragaman hayati. Bagi Indonesia, kekayaan sumberdaya hutan tersebut merupakan penyumbang yang nyata dan cukup penting bagi pertumbuhan ekonomi. Hal ini ditunjukkan oleh perannya dalam menunjang perekonomian nasional yang sangat nyata terutama pada periode 1970-1990, Pada tahun 1994 sektor kehutanan menyumbang devisa USD 4,2 Milyar (Departemen Kehutanan, 2000: 3). Peranan hasil hutan ini terhadap perekonomian Indonesia dapat dilihat tidak hanya dari perolehan devisa saja tetapi juga dari penyediaan lapangan kerja. Menurut Departemen kehutanan (2000), tenaga kerja yang terserap oleh sektor kehutanan adalah sekitar 5,4 \% dari total tenaga kerja Indonesia. Selain kinerja pada penyerapan tenaga kerja, sektor kehutanan juga menyumbang dalam penurunan tingkat penduduk miskin dari $60 \%$ pada tahun 1970 menjadi $11 \%$ pada tahun 1996 (World Bank, 1999).

Pembangunan kehutanan diarahkan utuk meningkatkan fungsi dan perannya dalam lingkungan hidup, sosial kemasyarakatan, memenuhi kebutuhan industri dan eksport, serta pendapatan bagi negara dan masyarakat.

Menurut Suntana et al (2000: 11) telah terjadi pergeseran bobot penanganan berbagai kegiatan yang selama ini dilaksanakan, dengan menyatakan:

1) Prinsip-prinsip kelestarian produksi (sustainable yield principles) ditingkatakan penanganannya sehingga lebih mengarah kepada kelestarian hutan dan 
ekosistemnya (sustainable forest management) di mana hasil hutan yang dimanfaatkan diperoleh dengan dasar pengelolaan lestari.

2) Mendorong agar keterlibatan masyarakat di sekitar hutan dan pengusaha menengah dan kecil dibidang kehutanan dapat ditingkatkan secara nyata, pergeseran dari economic growth ke social growth. Pengusaha besar dan BUMN diarahkan untuk mengembangkan ekonomi rakyat dan membina kemitraan dalam berusaha dengan masyarakat dan pengusaha kecil/menengah.

3) Meningkatkan pembangunan hutan rakyat dalam rangka meningkatkan produksi hasil hutan, pelestarian tanah dan air serta meningkatkan kesejahteraan masyarakat pedesaan.

4) Prioritas pembangunan lebih diarahkan pada daerah yang masih tertinggal, disesuaikan dengan kondisi alam, kondisi hutan, dan kondisi masyarakatnya.

5) Meningkatkan kemampuan faktor penujang pembangunan kehutanan (sumber daya manusia, IPTEK, kelembagaan dan investasi). Unsur ini sangat penting karena akan menjadi penggerak pembangunan kehutanan untuk jangka panjang.

Sumber daya hutan Indonesia memiliki peranan penting dalam menghasilkan devisa bagi negara. Pada masa-masa awal pembangunan, eksploitasi sumber daya hutan hanya berorientasi pada timber based management yang menitikberatkan pada manfaat ekonomi semata. Lebih jauh Suntana et al (2000: 5), mengemukakan bahwa setidaknya terdapat tiga manfaat sumber daya hutan, yaitu:

1) Sebagai sumber keanekaragaman jenis flora antara lain penghasil kayu, pangan, bahan serat, bahan parfun, bahan obat, bahan kimia alam, bahan penyamak, pewarna dan lain-lain;

2) Sebagai sumber keanekaragaman fauna antara lain penghasil protein, bahan obat, sumber genetik untuk pemuliaan ternak, burung, serangga, ikan reptil, madu, kulit, dan lain-lain, serta,

3) Sebagai sumber beranekaragam jasa yang sangat bermanfaat bagi kehidupan manusia, sperti jasa wisata alam, pengatur tata air dan iklim mikro, pendaurulangan $\mathrm{Co} 2$, perlindungan tanah, gudang plasma nutfah dan lain-lain.

Sumber daya hutan sesungguhnya memberikan manfaat yang banyak (multifunctional benefit), nilai kayu hanyalah sebagian kecil kecil dari nilai ekonomi manfaat sumber daya. Oleh karena itu orientasi kepada upaya optimalisasi pemanfaatan hutan secara majemuk dengan perspektif jangka panjang menjadi pilihan yang terbaik.

Memasuki abad 21, pembangunan kehutanan Indonesia dihadapkan pada permasalahan yang makin kompleks. Menurut Nurfatriani dan Sukadri (2000: 2) menyatakan bahwa:

Salah satu permasalahan yang dihadapi adalah masalah deforestasi hutan dengan laju yang tinggi. berdasarkan data Ditjen RLPS pada tahun 2000 mencapai 1,6 juta hektar/tahun. Dengan laju kerusakan yang tinggi tersebut luas hutan Indonesia mengalami penurunan yang signifikan, hal tersebut mengakibatkan sumber daya hutan Indonesia mengalami penurunan potensi yang sangat berarti. 
Kondisi kerusakan hutan dan lahan di Indonesia saat ini telah menjadi keprihatinan banyak pihak baik secara nasional maupun internasional. Fenomena degradasi sumberdaya hutan dan lahan terus meningkat baik kualitas maupun kuantitasnya. Data tentang kehutanan menunjukkan bahwa dalam 50 tahun terakhir, Indonesia telah kehilangan hutan seluas 60 juta hektar. Pada tahun 19851997, laju deforestasi di Indonesia mencapai 1,871 juta hektar pertahun. Muhtadi (2003) menyatakan bahwa di Jawa, tingkat kerusakan kawasan hutan yang dikelola oleh PT Perhutani, sampai tahun 2001 sudah mencapai 350.000 hektar.

Diperkirakan tingkat kerusakan hutan di Jawa akan meningkat hingga 500.000 hektar pada tahun 2006. Kerusakan ini tidak hanya terbatas pada kawasan hutan produksi, tetapi juga hutan lindung dan hutan alam. Sabarudin (2001: 1) menyatakan bahwa eksploitasi berlebih (over exploitation), pembalakan tak legal (illegal logging) dan merebaknya perambahan kawasan melengkapi proses destrukturisasi hutan di Indonesia. Keadaan ini makin diperparah pula oleh adanya tabrakan kebijakan-kebijakan perekonomian, sosial dan politik menyangkut sumber daya hutan.

Kerusakan hutan dan lahan tersebut telah mengakibatkan bencana alam yang besar, bahkan akhir-akhir ini kecenderungannya semakin meningkat, khususnya banjir, tanah longsor dan kekeringan. Bencana tersebut telah menimbulkan kerugian nasional yang besar berupa kerusakan infrastruktur, berbagai asset pembangunan serta terganggunya tata kehidupan masyarakat.

Penyebab utama terjadinya bencana tersebut adalah kerusakan lingkungan, terutama di wilayah hulu Daerah Aliran Sungai (DAS) sebagai daerah tangkapan air. Kondisi diatas menumbuhkan kesadaran dari semua pihak untuk melakukan Rehabilitasi Hutan dan Lahan (RHL) yang rusak guna memperbaiki dan mengembalikan fungsi dan produktivitas sumberdaya alam tersebut. Upaya tersebut juga dimaksudkan untuk menanggulangi bencana alam yang dilaksanakan secara terpadu, menyeluruh dan terkoordinasi.

Berdasarkan fenomena tersebut di atas, diperlukan suatu pemikiran yang serius mengenai pengelolaan hutan dimasa kini dan masa yang akan datang. Pengelolaan hutan di masa yang akan datang harus sejalan dengan arah pembangunan kehutanan di abad 21 yang telah bergeser dari orientasi ekonomi ke arah pembangunan kehutanan yang berorientasikan pada resources and community based development (Suntana et al (2000: 5), yang dijabarkan sebagai berikut :

(1) Perubahan orientasi produksi kayu dari hutan alam ke hutan tanaman;

(2) Perubahan orientasi dari hasil hutan kayu ke hasil hutan non kayu dan jasa; (3) Pergeseran pola pengusahaan hutan dari konglomerasi ke peningkatan peran masyarakat; (4) Perubahan bentuk pengelolaan hutan dari optimasi produksi log ke optimasi fungsi hutan; dan (5) Pergeseran kewenangan pengelolaan hutan dari sentralisasi ke desentralisasi.

Hutan merupakan salah satu sektor terpenting yang perlu mendapat perhatian, khususnya mengingat lebih $67 \%$ luas daratan Indonesia berupa hutan. Hutan adalah kekayaan alam yang dikuasai oleh Negara sesuai pasal 33 UUD 1945 "Bumi, air dan kekayaan alam yang terkandung didalamnya dikuasai oleh Negara 
dan dipergunakan sebesar-besarnya untuk kemakmuran rakyat". Akses dan hak pemanfaatan berbagai kategori hutan harus diatur sebaik-baiknya bagi semua kelompok masyarakat dengan memperhatikan berbagai aspek sebagaimana dinyatakan dalam Undang-undang Kehutanan No.4 Tahun 1999 pasal 2 "Penyelenggaraan kehutanan berasakan manfaat, dan lestari, kerakyatan, keadilan, kebersamaan, keterbukaan, dan keterpaduan". Dalam pasal selanjutnya disebutkan bahwa penyelenggaraan kehutanan bertujuan untuk kemakmuran rakyat dan keberlanjutan.

Menurut Caldwell (1999:7), hal-hal yang diperlukan agar pengelolaan lingkungan berhasil, yaitu:

(1) Koordinasi pendekatan berbagai disiplin untuk memecahkan masalah lingkungan; (2) Integrasi program-program lingkungan dengan upaya bidang lain misalnya dengan pertanian, kesehatan , transportasi; (3) Kesesuaian ruang lingkup organisasi dengan tugas-tugas yang dilaksanakan; (4) Merepresentasikan nilai-nilai lingkungan.

Melalui penetapan strategi pelestarian dunia tahun 1980/1981, Indonesia dikukuhkan sebagai negara maha aneka ragam (megadiversity country), sehingga Indonesia menjadi semakin penting dalam peta konservasi keanekaragaman hayati dunia. Indonesia menyusun rencana konservasi nasional tahun 1980 dan menetapkan target $30 \%$ dari luas kawasan hutan serta mengeluarkan kebijakan Tata Guna Hutan Kesepakatan (TGHK) yang diterapkan dalam mengukuhkan kawasan hutan di seluruh Indonesia (Mulyana, 2005 : 14).

Menindaklanjuti isu-isu strategi pelestarian dunia, dalam kongres Taman Nasional dan Kawasan Konservasi Nasional, mendeklarasikan berdirinya 11 Taman Nasional dengan luas total 3.287.063 hektar, membentuk Departemen Kehutanan, dan Ditjen PHPA. Dalam dokumen our common future (masa depan kita bersama) yang diterbitkan oleh World Commision On Environment and Development (komisi lingkungan dan pembangunan) tahun 1987 diperkenalkan gagasan "Pembangunan Berkelanjutan" beserta konsep-konsep demokrasi, keadilan, hubungan lingkungan dan pembangunan yang banyak diadopsi oleh pemerintah dan lembaga-lembaga internasional sebagai panduan bagi penyelenggaraan pembangunan yang berwawasan lingkungan.

Mengenai konsep pembangunan berkelanjutan, Sutikno dan Maryunani (2006:223) yang mengutip komisi Brundtland menyatakan bahwa pembangunan berkelanjutan adalah " Pembangunan yang mencukupi kebutuhan generasi sekarang tanpa membahayakan kemampuan generasi yang akan datang untuk memenuhi kebutuhan mereka". Jadi pembangunan berkelanjutan merupakan upaya yang dilakukan untuk melaksanakan pembangunan namun senantiasa memperhitungkan masa depan generasi yang akan datang.

Konsep pembangunan ini kemudian pada Earth Summit, 1992 di Rio de Janeiro, melahirkan agenda 21, pemerintah Indonesia menjabarkannya dalam dokumen "Agenda 21 Indonesia" yang berisi rumusan strategi nasional untuk pembangunan berkelanjutan, meliputi empat agenda; 
"(1) pelayanan masyarakat;(2) pengelolaan limbah;(3) pengelolaan sumberdaya tanah;(4) pengelolaan sumberdaya alam dengan salah satu sub agenda konservasi keanekaragaman hayati”

\section{Penutup}

Pelestarian telah menjadi isu penting dalam pembangunan, karena telah disadari bahwa eksploitasi sumber daya alam bisa mengakibatkan degradasi lingkungan. Meningkatnya kasus-kasus dalam sektor kehutanan, semakin menyadarkan kita bahwa melestarikan hutan memberikan banyak manfaat dalam kehidupan ini. Berbagai upaya telah ditempuh dalam rangka pelestarian sumber daya hutan, diantaranya adalah melakukan perubahan paradigma pengelolaan yaitu paradigm berkelanjutan (sustainable). Paradigma lama pengelolaan hutan dinilai telah mengakibatkan tidak tercapainya pengelolaan hutan secara adil dan lestari. Pada paradigma lama ini menempatkan hutan sebagai andalan untuk perolehan devisa dan ini dilakukan terutama melalui penerapan strategi ekspor, hal ini dijabarkan kedalam kebijakan pengusahaan hutan yang cenderung eksploitatif yang dicerminkan oleh munculnya banyak gejala negatif seperti kelebihan kapasitas, maraknya illegal logging, dan tingginya tingkat deforestasi hutan. Paradigma baru adalah bertumpu pada keseimbangan antar keberlanjutan fungsi ekonomi, ekologi dan sosial budaya dari pengelolaan sumberdaya hutan yang tidak sentralistik dengan membangun kemandirian masyarakat.

Untuk mencapai paradigma ini diperlukan; (1) reorientasi tujuan pembangunan nasional dan sektor kehutanan menuju keseimbangan antara keberlanjutan fungsi ekonomi, ekologi dan sosial budaya dalam pengelolaan sumber daya hutan bagi peningkatan kualitas hidup manusia; (2) kepemerintahan yang baik (good governance) dalam pengelolaan sumberdaya hutan yang dicirikan oleh berjalannya prinsip-prinsip keterbukaan, partisipasi masyarakat dan bertanggung gugat kepada publik; (3) usaha-usaha pemberdayaan para pihak berkaitan dengan penyesuaian/ reorientasi paradigma pembangunan nasional dan sektor kehutanan.

Akses dan hak pemanfaatan atas berbagai kategori hutan harus diatur sebaik-baiknya bagi semua kelompok masyarakat dengan memperhatikan berbagai aspek sebagaimana ditegaskan dalam Undang-undang Kehutanan No.41 Tahun 1999 pasal 2 "Penyelenggaraan kehutanan berasaskan manfaat dan lestari, kerakyatan, keadilan, kebersamaan, keterbukaan dan keterpaduan". penyelenggaraan kehutanan bertujuan untuk kemakmuran rakyat yang berkeadilan dan berkelanjutan. Pemanfaatan sumberdaya hutan dituntut untuk memperhatikan juga multiguna mencakup konservasi tanah dan air, sumber kayu dan non kayu untuk masyarakat lokal, konservasi flora dan fauna serta fungsi support untuk program pembangunan lainnya. 


\section{Daftar Pustaka}

Berkes, F. and C.Folke (eds).2000. Linking Social and Ecological System: Management Practices and Social Mechanisms for Building Resilience. New York: Cambridge University Press.

Boenjamin, S.A. 1991. Deforestasi dan Isu Pemanfaatan Lahan Yang Berkelanjutan di Indonesia. Jurnal Ekonomi dan Keuangan Vol.XXXIX No.3

Brooks, A., M.Zint,. R. DeYoung.2003. Land-Owners Response to Endangered Species Act Listing and Implications for Encouraging Conservation. Conservation Biology.13:1140-1150.

Caldwell, Lynton K. 1999. Management of Resources and Environment: A Problem in Administration Coordination, dalam Wolfgang Rudig (Editor), Environmental Policy Volume I, Cheltenham, Edward Elgar Publishing,Inc.

Departemen Kehutanan, 2000. Laporan Tahunan Departemen Kehutanan 1999/2000

Grumbine, E.R. 1994. What is Ecosystem Management?. Conservation Biology. 8:27-38.

Indrawan, Mochamad. Richard B.Primack,. Jatna Supriatna. 2007. Biologi Konservasi. Jakarta: Buku Obor.

Jeffries, Michael J. 2006. Biodiversity and Conservation. Second Edition. Canada: Rondledge.

Johnson, N.1995. Biodiversity inThe Balance: Approach to Setting Geographic Conservation Priorities. Biodiversity Support Program.World Wildlife Fun, Washington DC.

Muhtadi, D. 2003. Derita Sepanjang Masa Rakyat Jawa. Harian Kompas, 9 Pebruari, Jakarta: PT.Kompas Media Nusantara.

Mulyana, A. 2005. Melangkah Diatas Batu Karang, Pengelolaan Sumber daya Alam Berbasis Masyarakat di Nusa Tenggara. Sumba Timur NTT : Koppesda.

Nurfatriani, Fitri. Doddy S.Sukadri. 2001. Pengelolaan Hutan di Masa Depan : Berdasarkan Paradigma Pembanguan Kehutanan di Abad 21, Buletin Kehutanan Vol.2.

Sabarudin, S. 2001. Rekonsiliasi Nasional Untuk Menyelamatkan Hutan. Makalah Presentasi Kelompok Pada Konggres Kehutanan Indonesia III, Jakarta.

Sastroprawiro, Susetiyaningsih, 2008. Peringkat Hutan Kelas Dunia, Kompas 10 Desember 2008, Edisi Bandung.

Simon, Hasanu. 2006. Hutan Jati dan Kemakmuran, Problem dan Strategi Pemecahannya. Yogyakarta : Pustaka Pelajar.

Stanley, T. 1995. Ecosystem Management and the Arrogance of Humanism. Conservation Biology. 9: 254-262.

Suntana, Asep Sugih,. dkk. 2000. Agenda 21 Sektoral, Agenda Kehutanan Untuk Pengembangan Kualitas Hidup Secara Berkelanjutan. Jakarta : Kantor Menteri KLH.

Sutikno; Maryunani.,2006. Ekonomi Sumber Daya Alam, Malang: BPFE-Unibraw. 
Wiebecke, C. and W. Peters. 1984. Aspect of Sustained Yiel History Forest Sustention as the Principle of Forestry Idea and Reality, dalam History of Sustained Forestry.

World Bank,1990, Indonesia: Sustainable Development for Forests, Land and Water: Country Study. Report No.9212, Washington DC. 